\title{
GROWTH AND ACID TOLERANCE OF HUMAN DENTAL PLAQUE BACTERIA
}

\author{
D. S. HARPER ${ }^{*}$ and W. J. LOESCHE \\ Schools of Medicine and Dentistry, The University of Michigan, Ann Arbor, MI 48109, U.S.A.
}

\begin{abstract}
Summary-Pure cultures of representative strains of cariogenic and non-cariogenic plaque bacteria were assessed for their ability to initiate and maintain growth in broths, adjusted to initial pH levels of 7.0 , 5.5 or 5.0 , and to produce lactic acid from sucrose or glucose in resting-cell suspensions at pH 6.5, 5.0, 4.5 and 4.0. Streptococcus mutans, Lactobacillus casei and Streptococcus faecalis showed greater acid tolerance than strains of Streptococcus sanguis, Streptococcus salivarius, Streptococcus mitis and Actinomyces viscosus. For all species, growth initiation in broth was more acid sensitive than lactic-acid production in resting-cell suspensions. These data confirm and cxtend previous observations that the species of plaque bacteria most closely associated with the initiation or progression of dental caries are more aciduric than non-cariogenic species.
\end{abstract}

\section{INTRODUCTION}

Streptococcus mutan: is statistically associated with human dental decay (Krasse et al., 1968; Loesche, 1982 ) and shows a significant numerical increase with the initiation of dental decay in man (Ikeda and Sandham, 1971; Ikeda, Sandham and Bradley, 1973; Loesche and Straffor, 1979). Strep. mutans also produces high levels of rnultisurface caries in animals, in contrast with other species of dental bacteria which are less cariogenic (Dummer and Green, 1980; Hamada and Slade, 1980). Explanations for the high cariogenicity of Strep. mutans have been based upon its production from sucrose of extracellular polysaccharides which rnediate its adherence to tooth surfaces (Gibbons and Nygaard, 1968; Hamada and Slade, 1980); its formation of intracellular polysaccharide energy reserves (Gibbons, 1968; Hamilton, 1967); and the rapid metabolism of sugars to organic acids, particularly lactic acid (Minah and Loesche, 1977a,b). Acid tolerance (reviewed by van Houte, 1980; Loesche, 1982) has been proposed as another factor in the specific cariogenicity of Strep. mutans and Lactobacillus species, and could account for high levels of these bacteria in fissure plaque (Ikeda and Sandham, 1971; Ikeda et al., 1973; Theilade et al., 1978) and carious lesions (Loesche and Syed, 1973; Loesche et al., 1975). The $\mathrm{pH}$ of plaque in sites prone to caries drops rapidly upon ingestion of fermentable carbohydrates and can remain below pH 5.0 for substantial periods of time (Graf and Muhlemann, 1966; Schachtele and Jensen, 1982).

Aciduricity, as it has been applied to oral bacteria, has been defined as the ability to lower the terminal $\mathrm{pH}$ of carbohydrate-containing broths to $\mathrm{a} \mathrm{pH}$ of 4.5 to 4.0 , the ability to initiate growth at $\mathrm{pH}$ levels of $\mathrm{pH} 5.5$ or below, or the possession of a $\mathrm{pH}$-lowering potential at low pH levels (van Houte, 1980). Many studies have not distinguished between falls in $\mathrm{pH}$

*Present address: American Dental Association, Health Foundation, Research Institute, 211 East Chicago Avenue, Chicago, IL 60611, U.S.A. and specific acid production, or have not related aciduricity to growth rates at low $\mathrm{pH}$ levels. Our object was to compare the $\mathrm{pH}$-lowering potential and growth capacity of 30 strains of cariogenic and noncariogenic oral bacteria and the rate of lactic-acid production by resting-cell suspensions of selected strains.

\section{MATERIALS AND METHODS}

\section{Bacterial strains}

The bacterial strains used were obtained from frozen and lyophilized stocks maintained by $\mathrm{Dr}$ Loesche. Several strains (designated as recent isolates) were obtained from caries active children Loesche and Straffon, 1979) and used after a minimal number of in-vitro passages. Biotypes of all Strep. mutans isolates were confirmed using the metabolic assay of Shklair and Keene (1974).

All isolates were subcultured in Trypticase Soy Broth, (BBL, Cockeysville, Maryland, U.S.A.), concentrated by centrifugation and stored frozen in suspension with blood on glass beads (Nagel and Kunz, 1972). These glass beads, containing about $10^{7}$ colony-forming units (c.f.u.), then served as inocula for the tests to be described.

\section{Growth in pH-adjusted media}

The ability of 30 strains (Table 1) to establish growth in Trypticase Soy Broth (TSB) with 1 per cent additional glucose was determined at $\mathrm{pH} 7.0,5.5$ and 5.0 (initial $\mathrm{pH}$ adjusted with lactic acid). Broths were inoculated with $0.1 \mathrm{ml}$ of $18 \mathrm{~h}$ TSB cultures of streptococci or 24-h cultures of Actinomyces and Lactobacillus and incubated anaerobically ( 85 per cent $\mathrm{N}_{2}, 10$ per cent $\mathrm{CO}_{2}$ and 5 per cent $\mathrm{H}_{2}$ ) for $48 \mathrm{~h}$ at $5^{\circ} \mathrm{C}$

Terminal optical density (O.D.) was measured at $540 \mathrm{~nm}$ in a Spectronic 20 spectrophotometer (Bausch \& Lomb, Rochester, New York, U.S.A.), and terminal $\mathrm{pH}$ was determined with a combination glass electrode (Model MI410, Microelectrodes, Inc. Londonderry, New Hampshire, U.S.A.). Selected 
Table 1. Terminal $\mathrm{pH}$ and growth density of plaque bacteria initiated in TSB broths at $\mathrm{pH} 7.0,5.5$ or 5.0

\begin{tabular}{|c|c|c|c|c|c|c|c|c|c|}
\hline & \multicolumn{3}{|c|}{ Terminal O.D. } & \multicolumn{3}{|c|}{ Terminal $\mathrm{pH}$} & \multicolumn{3}{|c|}{ pH drop } \\
\hline & 7.0 & 5.5 & 5.0 & 7.0 & 5.5 & 5.0 & 7.0 & 5.5 & 5.0 \\
\hline \multicolumn{10}{|l|}{ Strep mutans: } \\
\hline AHT (a)* & 1.42 & 0.66 & 0.30 & 4.6 & 4.8 & 4.6 & 2.4 & 0.7 & 0.4 \\
\hline E49 (a) & 1.67 & 0.98 & 0.22 & 4.2 & 4.3 & 4.7 & 2.8 & 1.2 & 0.3 \\
\hline FAl (b) & 2.06 & 1.17 & 0.21 & 4.2 & 4.4 & 4.8 & 2.8 & 1.2 & 0.2 \\
\hline BHT (b) & 1.42 & 0.96 & 0.32 & 4.2 & 4.3 & 4.6 & 2.8 & 1.2 & 0.4 \\
\hline Ingbritt (c) & 1.46 & 0.77 & 0.27 & 4.3 & 4.3 & 4.6 & 2.7 & 1.2 & 0.4 \\
\hline$S(c)$ & 1.33 & 0.99 & 0.49 & 4.3 & 4.2 & 4.4 & 2.7 & 1.2 & 0.6 \\
\hline GS 5 (c) & 1.12 & 0.58 & 0.23 & 4.5 & 4.4 & 4.6 & 2.5 & 1.0 & 0.4 \\
\hline OMZ-175 (c) & 0.95 & 0.48 & 0.14 & 4.5 & 4.6 & 4.8 & 2.7 & 0.9 & 0.2 \\
\hline MI-33† (c) & 1.20 & 0.46 & 0.29 & 4.3 & 4.4 & 4.5 & 2.6 & 1.0 & 0.4 \\
\hline MI-76† (c) & 1.00 & 0.33 & 0.18 & 4.4 & 4.5 & 4.6 & 2.5 & 0.9 & 0.3 \\
\hline MI-186† (d) & 1.17 & 0.87 & 0.48 & 4.3 & 4.2 & 4.4 & 2.7 & 1.2 & 0.5 \\
\hline OMZ-176 (d) & 1.10 & 0.56 & 0.39 & 4.4 & 4.6 & 4.6 & 2.5 & 0.8 & 0.3 \\
\hline TH (d) & 0.78 & 0.39 & 0.20 & 4.7 & 4.5 & 4.6 & 2.2 & 0.9 & 0.3 \\
\hline BHR (d) & 0.96 & 0.36 & 0.34 & 4.7 & 4.7 & 4.6 & 2.2 & 0.7 & 0.3 \\
\hline MI-83† (d) & 0.94 & 0.51 & 0.31 & 4.5 & 4.4 & 4.5 & 2.4 & 1.0 & 0.4 \\
\hline B2 (e) & 1.32 & 0.69 & 0.31 & 4.4 & 4.5 & 4.6 & 2.5 & 0.9 & 0.3 \\
\hline LM7 (e) & 0.80 & 0.46 & 0.24 & 4.5 & 4.5 & 4.6 & 2.4 & 0.9 & 0.3 \\
\hline MI-158† (e) & 1,19 & 0.62 & 0.41 & 4.3 & 4.3 & 4.4 & 2.6 & 1.1 & 0.5 \\
\hline $6715(\mathrm{~g})$ & 1.00 & 0.68 & 0.41 & 4.4 & 4.7 & 4.5 & & & \\
\hline Average: & 1.20 & 0.68 & 0.30 & 4.4 & 4.4 & 4.6 & 2.6 & 1.0 & 0.3 \\
\hline $\begin{array}{l}\text { L. casei } 49 \mathrm{~L} \\
\text { Strep. faecalis }\end{array}$ & 1.37 & 1.2 & 1.02 & 4.2 & 4.0 & 4.0 & 2.8 & 1.42 & 0.95 \\
\hline DS27 & 1.59 & 0.78 & 0.65 & 4.5 & 4.4 & 4.4 & 2.4 & 1.0 & 0.5 \\
\hline \multicolumn{10}{|l|}{ Strep. sanguis: } \\
\hline 10558 & 1.56 & 0.36 & 0.01 & 4.4 & 4.7 & 5.0 & 2.5 & 0.7 & 0.0 \\
\hline $167 \mathrm{~N}$ & 1.03 & 0.27 & 0.01 & 4.4 & 4.7 & 5.0 & 2.5 & 0.7 & 0.0 \\
\hline S1-25† & 1.13 & 0.26 & 0.01 & 4.4 & 4.7 & 5.0 & 2.5 & 0.7 & 0.0 \\
\hline S1-26† & 1.13 & 0.12 & 0.01 & 4.5 & 5.1 & 5.0 & 2.4 & 0.3 & 0.0 \\
\hline \multicolumn{10}{|l|}{ Strep salivarius: } \\
\hline HHT & 1.21 & 0.30 & 0.01 & 4.5 & 4.8 & 5.0 & 2.4 & 0.7 & 0.0 \\
\hline $\mathrm{SS} 2$ & 1.12 & 0.17 & $0.0 !$ & 4.6 & 4.8 & 5.0 & 2.3 & 0.7 & 0.0 \\
\hline \multicolumn{10}{|l|}{ A. viscosus: } \\
\hline No. 21 & 1.49 & 0.20 & 0.01 & 4.6 & 5.0 & 5.0 & 2.3 & 0.4 & 0.0 \\
\hline GA & 1.02 & 0.16 & 0.01 & 4.6 & 5.1 & 5.0 & 2.3 & 0.4 & 0.0 \\
\hline Strep. mitis $2 \mathrm{~S}$ & 0.93 & 0.14 & 0.01 & 4.7 & 5.1 & 5.0 & 2.24 & 0.37 & 0.0 \\
\hline Average: & 1.24 & 0.33 & 0.01 & 4.6 & 4.9 & 5.0 & 2.4 & 0.5 & 0.0 \\
\hline
\end{tabular}

* Strep. mutans strains followed by serotype in parentheses. $\dagger$ Recent clinical isolate.

strains (Table 2) were incubated under similar conditions with O.D. measurements taken at hourly intervals up to $18 \mathrm{~h}$, then at 1,2 and 7 days.

\section{Carbohydrate catabolism assay}

Sucrose and glucose cataholism by resting cell suspensions of selected pure cultures was evaluated using a modification of the technique developed by Minah and Loesche (1976, 1977a). All streptococcal cultures were inoculated directly from glass-bead stocks into $5 \mathrm{ml}$ of TSB, and slower-growing Lactohacillus and Actinomyces strains were inoculated from 24-h broth cultures. As TSB contains sufficient trace sucrose to induce sucrose-inducible enzyme systems (Hamada and Slade, 1980), additional sucrose was not added to the broth. All cultures were incubated anaerobically under an atmosphere of 85 per cent $\mathrm{N}_{2}, 10$ per cent $\mathrm{CO}_{2}$ and 5 per cent $\mathrm{H}_{2}$ at $35^{\circ} \mathrm{C}$ for 16 to $18 \mathrm{~h}$. Cultures were centrifuged, washed once with reduced transport fluid $(\mathrm{RTF}$, Syed and
Loesche, 1972) and resuspended in RTF. Cell concentrations of the suspensions were determined turbimetrically, and adjusted to make all suspensions approximately equal in colony-forming unit concentration.

The cell suspensions were transported into an anaerobic chamber kept at $35^{\circ} \mathrm{C}$ (Aranki et al., 1969) and dispersed by $20 \mathrm{~s}$ of mild sonication (Cell Disruptor, Kontes Glass Co., Vineland, New Jersey, U.S.A.). Fifteen-microlitre samples were removed and diluted in RTF for later determination of viable counts. The RTF buffers used for washing and suspending the cells were adjusted to $\mathrm{pH} 6.5,5.0,4.5$ or 4.0 by mixing appropriate proportions of acidic and basic RTF stocks containing $9.96 \mathrm{mM}$ lactic acid and $5.17 \mathrm{mM} \mathrm{K}_{2} \mathrm{HPO}_{4}$, respectively.

The assay was started by adding $100 \mu \mathrm{l}$ of the cell suspensions to $150 \mu \mathrm{l}$ of RTF containing $1 \mu \mathrm{Ci}$ of $\left[\mathrm{U}-{ }^{14} \mathrm{C}\right]$-sucrose or $1 \mu \mathrm{Ci}$ of $\left[\mathrm{U}-{ }^{14} \mathrm{C}\right]$-glucose (New England Nuclear, Boston, Massachusetts, U.S.A.). Additional cold sucrose or glucose was added to 
bring the final concentration of sugar in the reaction mixture to 0.1 per cent.

At $2,5,10,20$ and $30 \mathrm{~min}, 1 \mu \mathrm{l}$ samples of the assay suspensions were spotted on thin-layer chromatography sheets. The sheets were dried, and developed using a solvent mixture of 88 per cent formic acid-2-butanone-t-butanol-water $\quad$ (15:30:40:15) (Minah and Loesche, 1976). Spots corresponding to lactic acid, which migrated separately from the other organic acids (Minah and Loesche, 1976), were removed, and their radioactivity determined in a liquid scintillation counter. Volatile acid production, although present in Actinomyces viscosus and Streptococcus sanguis, and to a lesser extent in Strep. mutans (Minah and Loesche, 1976), was not quantitated. At the conclusion of the experiment, all reaction mixtures were immediately frozen and stored until total protein content of each reaction mixture could be assayed by the microfluorometric technique of Undenfriend et al. (1972).

\section{Data analysis}

Data obtained from the resting cell metabolism assays were corrected for quenching, normalized in terms of suspension-protein concentration, and analysed using computer programs in the Michigan Inte active Data Analysis System (MIDAS). Significant differences among groups were evaluated using Student's $t$-test or the non-parametric Mann-Whitney $U$-test.

\section{RESULTS}

The terminal $(53 \mathrm{~h}) \mathrm{pH}$ and turbidity of cultures incubated in TSB-glucose broths with initial $\mathrm{pH}$ levels of $7.0,5.5$ or 5.0 are presented in Table 1. All 19 Strep. mutans strains established growth at the three $\mathrm{pH}$ levels, as did the Lactobacillus casei and Streptococcus faecalis strains. The terminal growth of the Strep. mutans and Strep. faecalis strains in the pH 5.5 medium was about 50 per cent and in the pH 5.0 medium about 20 per cent of that observed in the $\mathrm{pH} 7.0$ broth. The $L$. case $i$ strain exhibited a slight reduction in terminal growth in the pH 5.5 and pH 5.0 medium. Growth of all 9 strains of Strep. sanguis, Streptococcus salivarius, A. viscosus, and
Streptococcus mitis (non-cariogenic strains) inoculated at pH 5.5 was considerably less than the majority of Strep. mutans strains, and was completely inhibited at $\mathrm{pH}$ 5.0. The differences in terminal O.D. between the Strep. mutans strains, taken as a group, and the non-cariogenic strains were statistically significant $(p<0.05$; Student's $t$-test) for cultures inoculated in the $\mathrm{pH} 5.5$ and 5.0 broths.

The terminal $\mathrm{pH}$ levels of all cultures initiated at pH 7.0 were below 5.0 (Table 1); the average terminal $\mathrm{pH}$ of the Strep. mutans cultures was $0.2 \mathrm{pH}$ units lower than the average for the non-cariogenic bacteria $(p<0.05)$. The difference in average terminal $\mathrm{pH}$ between these two groups was significantly greater in cultures initiated at $\mathrm{pH} 5.5$ (4.46, compared to $4.91 ; p<0.01$ ). The Strep. mutans strains reduced the $\mathrm{pH}$ in the $\mathrm{pH} 5.0$ broth by about $0.4 \mathrm{pH}$ units whereas the less cariogenic strains did not grow. The terminal $\mathrm{pH}$ of the Strep. faecalis culture was similar to the Strep. mutans cultures, while that of the $L$. case $i$ cultures was lower, especially in those initiated at $\mathrm{pH} 5.5$ and 5.0 .

A summary of growth-curve data for 12 selected strains (Table 2) shows that the streptococci inoculated at $\mathrm{pH} 7.0$ had similar lag phases, with the exception of Strep. mutans OMZ-176, which had $4 \mathrm{~h}$, as opposed to $2 \mathrm{~h}$, lag time. The median log-phase growth rate for the streptococci inoculated at $\mathrm{pH} 7.0$ was 0.108 O.D. units/hour, with Strep. mutans strains FA1, E49 and 10558 growing appreciably $(>0.05$ units) faster than the median, and Strep. mitis $2 \mathrm{~S}$ growing appreciably slower than the median value. $A$. viscosus had the longest lag phase of the strains inoculated at $\mathrm{pH} 7.0$, and the $A$. viscosus and $L$. casei strains grew at slower rates than many of the streptococci. Initiation in $\mathrm{pH} 5.5$ broth increased the lag phase of all strains except Strep. sanguis SI-25 and Strep. mutans Ingbritt, and decreased the growth rates of all strains except $L$. casei $49 /$ L. Strep. mutans strains FA1 and OMZ-176 had log-phase growth rates approx. 50 per cent lower than those of strains E49, Ingbritt, and FA1. L. casei and Strep. faecalis had growth rates that were similar to the fastergrowing Strep. mutans strains. All the less cariogenic bacteria initiated at $\mathrm{pH} 5.5$, except Strep. sanguis strain SI-25, had lower growth rates during log phase

Table 2. Growth curve summary for plaque bacteria grown in TSB initiated at pH 7.0, 5.5 or 5.0

\begin{tabular}{|c|c|c|c|c|c|c|c|c|c|}
\hline \multirow[b]{2}{*}{ Initial $\mathrm{pH}$} & \multicolumn{3}{|c|}{ Terminal O.D. } & \multicolumn{3}{|c|}{ Duration of lag (h) } & \multicolumn{3}{|c|}{ Growth rate (O.D. units/h)* } \\
\hline & 7.0 & 5.5 & 5.0 & 7.0 & 5.5 & 5.0 & 7.0 & 5.5 & 5.0 \\
\hline \multicolumn{10}{|l|}{ Strain } \\
\hline Strep. mutan: E49 & 1.57 & 0.55 & 0.34 & 2 & 3 & 13 & 0.180 & 0.049 & 0.006 \\
\hline Strep. mutan: FA1 & 1.67 & 0.77 & 0.10 & 2 & 3 & 9 & 0.230 & 0.022 & 0.021 \\
\hline Strep. mutan: Ingbritt & 1.07 & 0.50 & 0.24 & 2 & 2 & 12 & 0.081 & 0.044 & 0.024 \\
\hline Strep. mutans OMZ-176 & 1.18 & 0.58 & 0.27 & 4 & 5 & 12 & 0.086 & 0.044 & 0.008 \\
\hline Strep. mutans LM7 & 0.92 & 0.40 & 0.15 & 2 & 8 & 12 & 0.104 & 0.027 & \\
\hline Strep. faecalis DS2 & 1.17 & 0.50 & 0.33 & 2 & 3 & 8 & 0.115 & 0.048 & 0.012 \\
\hline L. casei $49 \mathrm{~L}$ & 0.84 & 0.68 & 0.58 & 2 & 4 & 3 & 0.063 & 0.062 & 0.034 \\
\hline Strep. sanguis 10558 & 1.57 & 0.30 & NG & 2 & 4 & - & 0.151 & 0.014 & - \\
\hline Strep. sanguis SI-25 & 0.88 & 0.40 & NG & 2 & 2 & - & 0.096 & 0.042 & - \\
\hline Strep. salivarius HHT & 0.86 & 0.20 & $\mathrm{NG}$ & 2 & 4 & - & 0.122 & 0.014 & - \\
\hline Strep. mitis 2S & 0.65 & 0.04 & $\mathbf{N G}$ & 2 & 7 & - & 0.045 & 0.003 & - \\
\hline A. viscosus No. 21 & 1.27 & 0.17 & NG & 6 & 15 & - & 0.072 & 0.003 & \\
\hline Escherichia coli HV & 1.17 & 0.36 & NG & 2 & 7 & 一 & 0.098 & 0.034 & \\
\hline
\end{tabular}

${ }^{*}$ Growth rates were determined during log-phase growth. NG $=$ No growth. 
than did the Strep. mutans strains. Cultures initiated at $\mathrm{pH} 7.0$ and 5.5 appeared to enter resting phase at approximately the same time. The slowest growth rates were observed in the cultures initiated at $\mathrm{pH}$ 5.0.

In other experiments, the rates of lactic acid production by resting cell suspensions of selected cariogenic and less cariogenic strains were determined at $\mathrm{pH} 6.5,5.0,4.5$ or 4.0 . Strep. mutans strain Ingbritt produced more lactic acid from both glucose and sucrose at pH 5.0 than at $\mathrm{pH} 6.5,4.5$ or 4.0 (Fig. 1A). Al $\mathrm{pH} 4.5$, acid production from glucose but not sucrose was increased in relation to that at $\mathrm{pH} 6.5$. At pH 4.0, acid production from sucrose was moderately inhibited compared to that at $\mathrm{pH} 6.5$, but acid production from glucose was not inhibited.

$L$. case strain $54 / \mathrm{L}$ showed a slow and variable production of lactic acid from sucrose, but lactic acid production from glucose proceeded rapidly (Fig. 1B). Unlike Strep. mutans, $L$. casei strain $54 / \mathrm{L}$ did not reveal a stimulation of lactic acid production at pH 5.0 compared to that at $\mathrm{pH} 6.5$, but rather, in the case of glucose, showed an approx. 20 per cent decrease in lactic acid production. Lactic acid production at $\mathrm{pH} 4.5$ and 4.0 was decreased 30 to 50 per cent compared to that at $\mathrm{pH} 6.5$. However, the amount of lactic acid production from glucose at $\mathrm{pH} 4.0$ by strain $54 / \mathrm{L}$ was higher than that of the other strains studied.

Lactic-acid production by resting-cell suspensions of Actinomyces viscosus strain No. 21 was more variable than was acid production by the streptococci. However, it was apparent that more lactic acid was produced from glucose than sucrose at $\mathrm{pH} 6.5,5.0$ or 4.5 , with a $\mathrm{pH}$ optimum of 4.5 for glucose catabolism (Fig. 1C). Acid production from both sugars was almost completely inhibited at $\mathrm{pH} 4.0$.

The pattern of lactic acid production from glucose and sucrose at the four $\mathrm{pH}$ levels by Strep. sanguis strains 10556, 10558, and SI-26 (Fig. 2) differed from that observed with Strep. mutans strain Ingbritt. At pH 6.5, acid production by Strep. sanguis strains 10556 and SI-26 was greater than that of Ingbritt. At $\mathrm{pH}$ 5.0, lactic-acid production from sucrose and glucose was less than, or approximately equal to, that at $\mathrm{pH}$ 6.5. This was in contrast to the marked stimulation of acid production at $\mathrm{pH} 5.0$ by Ingbritt, although strain SI-26 did show enhanced lactic-acid production from glucose after $30 \mathrm{~min}$. Acid production from sucrose at $\mathrm{pH} 4.5$ and 4.0 was inhibited compared to that at $\mathrm{pH} 6.5$. At $\mathrm{pH} 4.5$ and 4.0 , acid production from glucose was also inhibited in strains 10558 and SI-26, but acid production by strain 10556 was not inhibited until $\mathrm{pH} 4.0$ was reached. The amount of acid produced at the lower pH levels by the Strep. sanguis strains was less than that produced by Strep. mutans Ingbritt.

\section{DISCUSSION}

Strep. mutans and various Lactobacillus species are clearly associated with coronal caries in man (Krasse et al., 1968; Ikeda et al., 1973; Loesche and Syed, 1973; Loesche et al., 1975; Loesche and Straffon, 1979; Loesche, 1982). L. casei and Strep. faecalis can cause fissure caries, but not high levels of smooth-surface caries in rats (Fitzgerald, Jordan and Archard, 1966; Dummer and Green, 1980). A. viscosus is associated with root-surface caries but not coronal caries (Jordan and Sumey, 1973; Sycd and Loesche, 1975). Strep. sanguis, Strep. salivarius, Strep. mitis and A. viscosus are less cariogenic in animal models than Strep. mutans (Dummer and Green, 1980; Hamada and Slade, 1980).

Our study confirms the greater acid tolerance of Sirep. mutans and L. casei in comparison to a variety of other plaque species. This aciduricity was seen not only in their ability to initiate and maintain growth at low $\mathrm{pH}$ levels, as described by previous authors (reviewed by van Houte, 1980; Loesche, 1982) but also in the ability to produce lactic acid in lactate buffers below pH 5.0. Ingbritt cell suspensions incubated in acetate and phosphate-based buffer systems also exhibited increased lactate production at $\mathrm{pH} 5.0$ as compared to pH 6.5 (Harper and Loesche, 1983), indicating that this phenomenon was related to $\mathrm{pH}$ rather than to the lactate concentration of the buffer. Both manifestations of aciduricity would be expected to contribute to the pathogenicity of these organisms in the caries process.

The $\mathrm{pH}$ ranges studied here were lower than those reported in most previous in-vitro studies, but represent $\mathrm{pH}$ levels that are achieved in vivo for considerable periods in those sites most prone to carious

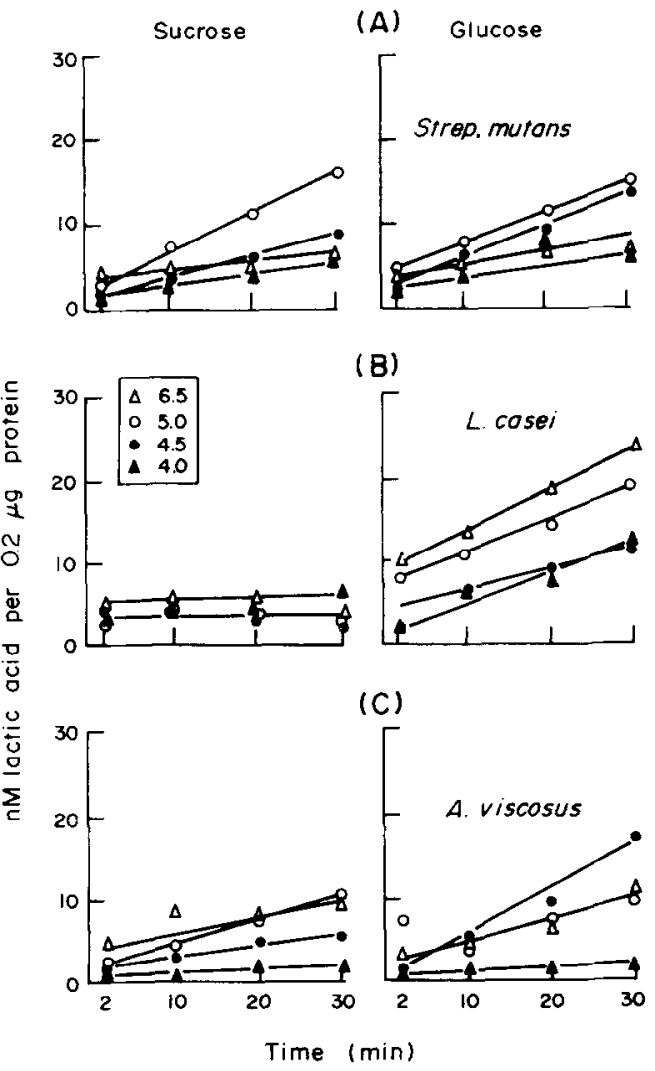

Fig. 1. Lactic-acid production from 0.1 per cent sucrose or glucose by resting-cell suspensions of Strep. mutans Ingbritt (A), L. casei 54/L (B) and A. viscosus strain 21 (C) incubated at pH 6.5, 5.0, 4.5 and 4.0. Points represent the mean of 4 to 8 repetitions. 


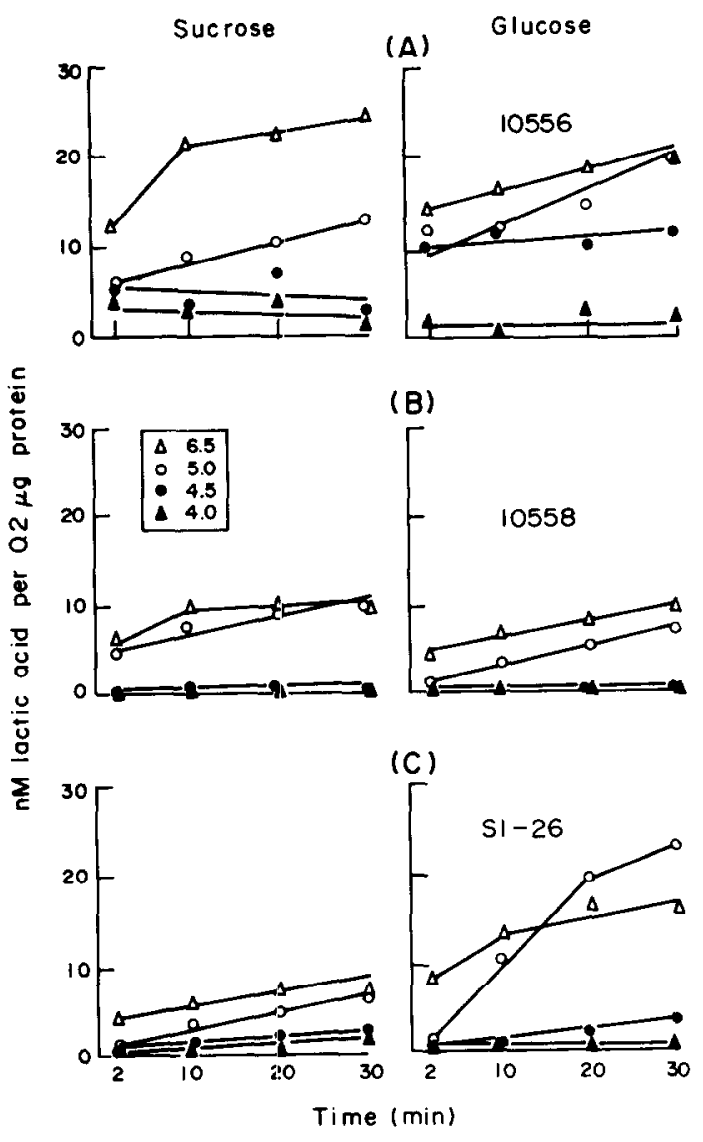

Fig. 2. Lactic-acid prcduction from 0.1 per cent sucrose or glucose by resting-cell suspensions of Strep. sanguis strains 10556 (A), 10558 (B) and SI-26 (C) incubated at pH 6.5, 5.0, 4.5 and 4.0 . Points represent the mean of 4 to 8 repetitions.

attack (Graf and Muhlemann, 1966; Schachtele and Jensen, 1982). The pattern of increased acidogenesis by Strep. mutans Ingbritt at pH 5.0 is shared by other serotypes with strains of Strep. mutans (Harper and Loesche, 1983), and is supportive of the observation of Hamilton and Ellwood (1978) that Strep. mutans Ingbritt cells grown in a chemostat at a constant $\mathrm{pH}$ of 5.5 were more metabolically active than cells grown at a constant $\mathrm{pH}$ of 6.5 and 6.0. However, these investigators did not find any increase in the metabolic rate of resting cells incubated at $\mathrm{pH} 5.5$ in comparison to those incubated at $\mathrm{pH} 6.5$ and 6.0. It may be that $\mathrm{pH} 5.5$ falls above a threshold for acidogenic stimulation of Strep. mutans.

The differences in acid-forming ability of Strep. mutans and Strep. sanguis at low $\mathrm{pH}$ levels are in agreement with the results of Komiyama and Kleinberg (1974) and with the findings of Futakami, Sato and Iwami (1976), who reported that glucose uptake and acid production by Strep. mutans cells incubated at pH 5.0 or 4.5 were greater than that of Strep. sanguis strains. Our observations also complement those of Onose and Sandham (1976) and Ellen and Onose (1978), who reported that Strep. mutans colonies produced a greater local $\mathrm{pH}$ depression on agar media than did colonies of $A$. viscosus or Strep. mitis. The slow rate of sucrose metabolism demonstrated by
L. casei $54 / L$ is characteristic of many $L$. casei strains (Buchanan and Gibbons, 1974).

The inferior ability of the non-cariogenic bacteria to initiate growth at $\mathrm{pH} 5.5$ and 5.0 when compared to Strep. mutans, L. casei and Strep. faecalis strains is in agreement with earlier studies, as is the observation of slightly different terminal $\mathrm{pH}$ values between the cariogenic and less cariogenic species (van Houte, 1980). The ability of the cariogenic bacteria to maintain growth at $\mathrm{pH} 5.0$ may be more significant in terms of cariogenicity than the fact that the cariogenic strains, taken as a group, achieved a statistically significant lower terminal $\mathrm{pH}$ from all three initial $\mathrm{pH}$ levels than did the less cariogenic organisms. The additional ability of the Strep. mutans and $L$. casei resting-cell suspensions to maintain acid production at low $\mathrm{pH}$ levels in comparison with the less cariogenic Strep. sanguis strains (Figs 1 and 2) would also contribute to their cariogenicity, especially in fissures or carious lesions, where $\mathrm{pH}$ can remain below 4.5 for hours (Dirksen, Little and Bibby, 1963).

The greater acidogenicity of the cariogenic bacteria at low $\mathrm{pH}$ levels may be due to more acid-tolerant sugar-uptake systems than exist in the less cariogenic species such as Strep. sanguis (Komiyama and Kleinberg, 1974; Kashket, Rodriguez and Bunich, 1977). A detailed examination of the glycolytic pathway metabolism in Strep. mutans and Strep. sanguis (Iwami and Yamada, 1980), showed that Strep. sanguis produced less acid at low $\mathrm{pH}$ levels than did Strep. mutans. This difference was apparently caused by inhibition of ATP-dependent glucose phosphotransferase-mediated glucose transport. A similarly detailed study of Actinomyces and Lactobacillus strains has not yet been carried out. Another possible mechanism of aciduricity might be related to the ability of Strep. mutans to maintain a neural internal $\mathrm{pH}$ under conditions of increasing ambient acidity, as shown by Whitford et al. (1977), and Eisenberg, Bender and Marquis (1980). The ability of other oral bacteria to maintain such a $\mathrm{pH}$ gradient has not yet been studied.

No previous investigations have compared specific production of lactic acid from sucrose and glucose at the low $\mathrm{pH}$ levels reported here. At pH 6.5, lactic acid production from the two sugars proceeded at approximately equal rates in all species tested. However, at the lower $\mathrm{pH}$ levels, lactic acid production from sucrose was more inhibited than that from glucose. The reason for this difference in $\mathrm{pH}$ sensitivity of acid production from the two sugars is not known, but could reflect differences in $\mathrm{pH}$ optima of transport mechanisms for the two sugars. The differences underscore the importance of considering sucrose as well as glucose in metabolic activity studies, as sucrose is the predominant dietary sugar consumed by man.

Acknowledgements - We wish to thank Charles Patterson and Graham Parkinson for their valuable technical assistance, and Nancy Starks and Sandra Harris for their secretarial assistance. This investigation was supported in part by Public Health Service Grants DE03423 and DE03011 from the National Institute of Dental Research, Bethesda, Maryland, U.S.A. The work forms part of a 
dissertation submitted to the Graduate School, The University of Michigan, in partial fulfillment of the requirements for the Ph.D. degree.

\section{REFERENCES}

Aranki A., Syed S. A., Kenney A. B. and Freter R. (1969) Isolation of anaerobic bacteria from human gingiva and mouse cecum by means of a simplified glove box procedure. Appl. Microbiol. 17, 568-576.

Buchanan R. E. and Gibbons N. E. (Ed.) (1974) Bergey's Manual of Determinative Bacteriology, 8th edn, p. 583. Williams \& Wilkins, Baltimore.

Dirksen T. R., Little I. M. F. and Bibby B. G. (1963) The $\mathrm{pH}$ of carious cavities II. The $\mathrm{pH}$ at different depths in isolated cavities. Archs oral Biol. 8, 91-97.

Dummer P. M. H. and Green R. M. (1980) A comparison of the ability of strains of streptococci to form dental plaque-like deposits in vitro with their cariogenicity in gnotobiotic rats. Archs oral Biol. 25, 245-249.

Eisenberg A. D., Bender G. R. and Marquis R. E. (1980) Reduction in the aciduric properties of the oral bacterium Streptococcus mutans GS-5 by fluoride. Archs oral Biol. 25, 133-135.

Ellen R. P. and Onose H. (1978) $\mathrm{pH}$ measurements of Actinomyces colonies grown on media containing dietary carbohydrates. Archs oral biol. 23, 105-109

Fitzgerald R. J., Jordan H. V. and Archard H. O. (1966) Dental caries in gnotobiotic rats infected with a variety of Lactobacillus acidophilus. Archs oral Biol. 11, 473-476.

Futakami K., Sato S. and Iwami Y. (1976) Lactate formation at various $\mathrm{pH}$ levels by the wild strain of Streptococcus mutans $\mathrm{PK} 1$, its variant, and $S$. sanguis. J. dent. Res. 55, 1131.

Gibbons R. J. and Nygaard M. (1968) Synthesis of insoluble dextran and its significance in the formation of gelatinous deposits by plaque-forming streptococci. Archs oral Biol. 13, $1249-1262$.

Gibbons R. J. (1968) Formation and significance of bacterial polysaccharides in caries etiology. Caries Res. 2, 164-171.

Graf $\mathrm{H}$. and Muhlemann H. R. (1966) Telemetry of plaque $\mathrm{pH}$ from interdental areas. Helv. odont. Acta 10, 94-101.

Hamada S. and Slade H. D. (1980) Biology, immunology and cariogenicity of Streptococcus mutans. Microbiol. Rev. 44, 331-384.

Hamilton I. R. (1967) Intracellular polysaccharide synthesis by cariogenic microorganisms. In: Proceedings of Microbial Aspects of Dental Caries (Edited by Stiles, Loesche and O'Brien) Sp. Suppl Micro. Abstr. Vol. III, pp. 683-702.

Hamilton I. R. and Ellwood D. C. (1978) Effects of fluoride on carbohydrate metabolism by washed cells of Streptococcus mutans grown at various $\mathrm{pH}$ values in a chemostat. Infect. Immun. 19, 434-442.

Harper D. S. and Loesche W. J. (1983) Effect of $\mathrm{pH}$ upon sucrose and glucose catabolism by various genogroups of Streptococcus mutans. J. dent. Res. 62, 526-531.

Ikeda T. and Sandham H. T. (1971) Prevalence of Streptococcus mutans on various tooth surfaces in negro children. Archs oral Biol. 16, 1237-1240.

Ikeda T., Sandham H. T. and Bradley E. L. Jr (1973) Changes in Streptococcus mutans and lactobacilli in plaque in relation to the initiation of dental caries in negro children. Archs oral Biol. 18, 555-566.

Iwami Y. and Yamada T. (1980) Rate-limiting steps of the glycolytic pathway in the oral bacteria Streptococcus mutans and Streptococcus sanguis and the influence of acidic $\mathrm{pH}$ on the glucose metabolism. Archs oral Biol. 25, 163-169.

Jordan H. V. and Sumey D. L. (1973) Root surface caries: Review of the literature and significance of the problem. J. Periodont. 44, 158-163.

Kashket S., Rodriguez V. M. and Bunich P. J. (1977) Inhibition of glucose utilization in oral streptococci by low concentration of fluoride. Caries Res. 11, 301-307.

Komiyama K. and Kleinberg I. (1974) Comparison of glucose utilization and acid formation by Strep. mutans and Strep. sanguis at different pH. J. dent. Res. 53, 746 (abstract).

Krasse B., Jordan H. V., Edwardsson S., Svensson I. and Trell L. (1968) The occurrence of certain "cariesinducing" streptococci in human dental plaque material. Archs oral Biol. 13, 911-918.

Loesche W. J. and Syed S. A. (1973) The predominant cultivable flora of carious plaque and carious dentine. Caries Res. 7, 201-216.

Loesche W. J., Rowan J., Straffon L. H. and Loos P. J. (1975) Association of Streptococcus mutans with human dental decay. Infect. Immun. 11, 1252-1260.

Loesche W. J. and Straffon L. H. (1979) Longitudinal investigations of the role of Streptococcus mutans in human fissure dccay. Infect. Immun. 26, 498-507.

Loesche W. J. (1982) Dental Caries: A Treatable Infection, $558 \mathrm{pp}$. Charles Thomas, Springfield, IL.

Minah G. and Loesche W. J. (1976) Development of methods to analyze sucrose metabolism by small dental plaque suspensions. In: Proceedings of Microbiol Aspects of Dental Caries (Edited by Stiles, Loesche and O'Brien). Sp. Supp. Micro. Abstr. Vol. II, pp. 491-520.

Minah G. E. and Loesche W. J. (1977a) Sucrose metabolism in resting-cell suspensions of caries-associated and noncaries-associated dental plaque. Infect. Immun. 17, 43-54.

Minah G. E. and Loesche W. J. (1977b) Sucrose metabolism by prominent members of the flora isolated from cariogenic and non-cariogenic dental plaques. Infect. Immun. $17,55-61$.

Nagel J. C. and Kunz L. J. (1972) Simplified storage and retrieval of stock cultures. Appl. Microbiol. 23, 837-840.

Onose H. and Sandham H. J. (1976) pH changes during culture of human dental plaque streptococci on mitissalivarius agar. Archs oral Biol. 21, 291-296.

Schachtele C. F. and Jensen M. E. (1982) Comparison of methods for monitoring changes in the $\mathrm{pH}$ of human plaque. $J$. dent. Res. 61, 1117-1125.

Shklair I. L. and Keene H. J. (1974) A biochemical scheme for the separation of five varieties of Streptococcus mutans. Archs oral Biol. 19, 1079-1081.

Syed S. A. and Loesche W. J. (1972) Survival of human dental plaque flora in various transport media. Appl. Microbiol. 24, 638-644.

Syed S. A. and Loesche W. J. (1975) Predominant cultivable flora isolated from human root surface caries plaque. Infect. Immun. 11, 727-731.

Theilade E., Fejerskov O., Karring T. and Theilade J. (1978) A microbiological study of old plaque in occlusal fissures of human teeth. Caries Res. 12, 313-319.

Undenfriend S., Stein S., Bohler P., Dairman W., Liemgruber W. and Weigele W. (1972) Fluorescamine: A reagent for assay of amino acids, peptides, proteins, and primary amines in the picomole range. Science 178, $871-882$.

van Houte J. (1980) Bacterial specificity in the etiology of dental caries. Int. dent. J. 30, 305-326.

Whitford G. M., Schuster G. S., Pashley D. H. and Venkateswarlu P. (1977) Fluoride uptake by Streptococcus mutans 6715. Infect. Immun. 18, 680-687. 